\title{
COVID-19 in South Korea: The Need for Preemptive Tests from the Perspective of Asymptomatic Infections
}

\author{
Insuk Sim ${ }^{1}$, Yun-Jung Kang ${ }^{2 *}$ (D) and Hye Jeong Kim ${ }^{3}$ \\ ${ }^{1}$ Department of Clinical Laboratory Science, Kyungdong University, Wonju 26495, Republic of Korea. \\ ${ }^{2}$ Department of Clinical Laboratory Science, Ansan University, Ansan 15328, Republic of Korea. \\ ${ }^{3}$ Department of Biomedical Laboratory Science, Kyungwoon University, Gumi 39160, Republic of Korea.
}

\begin{abstract}
The first case of coronavirus disease reported in South Korea was a person infected with severe acute respiratory syndrome coronavirus 2 (SARS-CoV-2), who entered South Korea from China on January 20, 2020. In the Capital, the Korean government applied the social distancing policy at level 2.5 for 8 days from August 30 to September 6, 2020. The Central Disease Relief Center explained that the reason the number of newly confirmed cases per day did not fall below 100 was because the infection spread nationwide through sporadic mass infections or asymptomatic patients. Asymptomatic infection with SARS-CoV-2 is a subject of constant controversies, as asymptomatic patients can infect other people while not showing any symptoms themselves. Their atypical clinical characteristics in the early stages of the disease make prevention more difficult. Additional studies on the infecting power of SARS-CoV-2 in asymptomatic cases are needed. Nonetheless, such probabilities should be taken into consideration and we should remain vigilant.
\end{abstract}

Keywords: COVID-19, preemptive tests, SARS-CoV-2, social distancing level 2.5, asymptomatic infection

\footnotetext{
*Correspondence: Ivpig@naver.com; +82-31-400-6933
}

(Received: November 24, 2020; accepted: February 25, 2021)

Citation: Sim I, Kang Y-J, Kim HJ. COVID-19 in South Korea: The Need for Preemptive Tests from the Perspective of Asymptomatic Infections. J Pure Appl Microbiol. 2021;15(2):590-593. doi: 10.22207/JPAM.15.2.13

(C) The Author(s) 2021. Open Access. This article is distributed under the terms of the Creative Commons Attribution 4.0 International License which permits unrestricted use, sharing, distribution, and reproduction in any medium, provided you give appropriate credit to the original author(s) and the source, provide a link to the Creative Commons license, and indicate if changes were made. 
On January 20, 2020, the first case of severe acute respiratory syndrome coronavirus 2 (SARS-CoV-2) infection was diagnosed in South Korea in a patient entering the country from China $^{1}$. Coronaviruses frequently cause respiratory infections. Excluding SARS-CoV-2, there are six major species known to cause human infections, which include the highly pathogenic SARS-CoV, Middle East Respiratory Syndrome Coronavirus (MERS-CoV), and the less virulent species NL63, 229E, OC43 and HKU14². The disease caused by SARS-CoV-2 is called coronavirus disease (COVID-19) and is characterized by fever, cough, and dyspnea ${ }^{3}$.

According to the Central Disease Relief Center, at 00:00 a.m. August 29, 2020, 323 new confirmed cases of COVID-19 were diagnosed, with the total number of patients reaching 19,400. In the period between August 14 and 16, over 100 new confirmed cases were reported per day, when mass infection was rampant in the Capital. The total number of newly confirmed cases by the end of this period was 4,630. Among them, 308 patients had acquired the infection locally and only 15 cases had returned from abroad ${ }^{4}$. From August 30 to September 6 , the Korean government applied the social distancing policy at level 2.5 in the Capital for 8 days. The level 2.5 social distancing policy is an intensification of the same policy at stage 2 , which restricts the operation of businesses and the opening times for cafes and restaurants to establish preventive measures in high-risk facilities to match those of stage 3 (Table $1)$.

The Central Disease Relief Center explained that the reason the number of newly confirmed cases per day did not fall under 100 was because the infection continued to spread nationwide through sporadic mass infections or asymptomatic patients. When tracing the contacts

Table 1. Step-by-step measures for social distancing

\begin{tabular}{|c|c|c|c|}
\hline & Level 1 & Level 2 & Level 3 \\
\hline $\begin{array}{l}\text { Gathering, } \\
\text { meeting, event }\end{array}$ & $\begin{array}{l}\text { permit } \\
\text { (Recommendation to comply } \\
\text { with quarantine regulations) }\end{array}$ & $\begin{array}{l}\text { Indoor 50/ } \\
\text { No more than } 100 \\
\text { people outdoors }\end{array}$ & No more than 10 people \\
\hline $\begin{array}{l}\text { Public multiple } \\
\text { facilities }\end{array}$ & $\begin{array}{l}\text { Allow operation (restrict } \\
\text { some operations if } \\
\text { necessary) }\end{array}$ & Downtime & Downtime \\
\hline $\begin{array}{l}\text { Private } \\
\text { multiple } \\
\text { facilities }\end{array}$ & $\begin{array}{l}\text { Operation allowed / High } \\
\text { risk facilities are } \\
\text { ordered to refrain from }\end{array}$ & $\begin{array}{l}\text { Suspension of high-risk } \\
\text { facilities operation / } \\
\text { Compulsory compliance } \\
\text { with other quarantine rules }\end{array}$ & $\begin{array}{l}\text { Suspension of operation } \\
\text { of high and medium-risk } \\
\text { facilities/forced compliance } \\
\text { with other quarantine rules }\end{array}$ \\
\hline $\begin{array}{l}\text { Kindergarten/ } \\
\text { Elementary } \\
\text { and Middle } \\
\text { School }\end{array}$ & $\begin{array}{l}\text { School attendance, } \\
\text { remote class } \\
\text { Maintaining } 2 / 3 \text { density } \\
\text { on campus }\end{array}$ & $\begin{array}{l}\text { Attending school. } \\
\text { Remote class } \\
\text { The density of Yu, } \\
\text { Elementary and Middle } \\
\text { School 1/3, High school 2/3 } \\
\text { maintained }\end{array}$ & $\begin{array}{l}\text { Remote class or closure / } \\
\text { national adjustment }\end{array}$ \\
\hline $\begin{array}{l}\text { Public } \\
\text { institutions }\end{array}$ & $\begin{array}{l}\text { Minimization of density } \\
\text { through flexible and } \\
\text { telecommuting through } \\
\text { flexible and telecommuting }\end{array}$ & $\begin{array}{l}\text { Recommend to limit } \\
\text { the number of workers }\end{array}$ & $\begin{array}{l}\text { Working from home } \\
\text { outside the required } \\
\text { number of people }\end{array}$ \\
\hline $\begin{array}{l}\text { Private } \\
\text { institutions and } \\
\text { companies }\end{array}$ & $\begin{array}{l}\text { Recommended for } \\
\text { flexible and } \\
\text { telecommuting }\end{array}$ & $\begin{array}{l}\text { Recommend to limit } \\
\text { the number of workers } \\
\text { through flexible and } \\
\text { telecommuting }\end{array}$ & $\begin{array}{l}\text { Recommended to work } \\
\text { from home outside of the } \\
\text { required personnel }\end{array}$ \\
\hline Sports event & $\begin{array}{l}\text { Limit the number of } \\
\text { attendees }\end{array}$ & No spectators & Stop the game \\
\hline
\end{tabular}

[source] The Korea Centers for Disease Control and Prevention 
of confirmed cases of infection, where the source of infection could not be found, asymptomatic cases counted for $30 \%-40 \%$ of the total number for sources of infection. Thus, the Center urged the public to follow three guidelines. First, people should be aware that they can be infected simply by meeting other people, further emphasizing the need for maintaining social distancing. Second, going out when necessary and wearing masks properly on these occasions. Masks should cover the mouth and nose completely, and people should avoid touching the surface of their masks. Third, the distance to be kept between people should be over $2 \mathrm{~m}$. Hence, avoid populated and closed places where crowds gather ${ }^{5}$. According to a research done by a team in Korea University in South Korea during the early stages of the disease, 3 among 28 confirmed cases of COVID-19 did not present with any symptoms and the patients themselves did not feel any different. Besides, as there were a wide range of symptoms, which did not match those generally observed in respiratory diseases, the research team concluded that early diagnosis and prevention may be difficult ${ }^{6}$. During the early periods, patients with COVID-19 presented with fever, cough, and sore throat. However, only 20 among the 28 patients showed these symptoms, with only 8 of them (40\%) having fever from the early stages. Some patients did not complain of cough and sore throat at any time during their disease, not to mention that some patients had only mild cough, whereas others reported severe sore throat.

In the 3 months from June 15 to September 14, the Seoul Emergency Management Agency conducted 8,544 preemptive tests for COVID-19 in volunteers from the general population, to detect asymptomatic cases of infection. Only one case of infection was confirmed during this process in a person who had applied for the preemptive test via Seoul City Government's website and been tested on September 14, after which the authority took follow-up measures to quarantine the person and provide care as per the COVID-19 instructions. The agency further reported that this experience had emphasized the need for preemptive tests to be conducted in the general public and high-risk facilities? ${ }^{7}$.

Asymptomatic infection of SARS-CoV-2 is a subject of constant controversies, as these cases can infect other people while not having any symptoms themselves; their atypical clinical characteristics in the early stages of the disease are major factors that make prevention more difficult. Additional studies on the infecting power of SARSCoV-2 in the asymptomatic state are needed. Nonetheless, such probabilities should be taken into consideration and we should remain vigilant.

\section{ACKNOWLEDGMENTS}

This work was supported by Basic Science Research Program through the National Research Foundation of Korea (NRF).

\section{CONFLICT OF INTEREST}

The authors declare that there is no conflict of interest.

\section{AUTHORS' CONTRIBUTION}

YJK, ISS and HK wrote the entire manuscript All the authors read and approved the manuscript for publication.

\section{FUNDING}

This work was funded by the Ministry of Science and ICT (No. 2018R1C1B5086313).

\section{DATA AVAILABILITY}

The datasets used and/or analyzed during the current study are available from the corresponding author on reasonable request.

\section{ETHICS STATEMENT}

Not applicable.

\section{REFERENCES}

1. Korea Centers for Disease Control and Prevention. 2019. https://www.cdc.go.kr/board.es? mid=a205 $01000000 \&$ bid $=0015 \&$ act $=$ view \&list_no $=143387$ (Korean).

2. Su S, Wong G, Shi W, et al. Epidemiology, genetic recombination, and pathogenesis of coronaviruses. Trends Microbiol. 2016;24(6):490-502. doi: 10.1016/j. tim.2016.03.003

3. Huang C, Wang Y, Li X, et al. Clinical features of patients infected with 2019 novel coronavirus in Wuhan China. The Lancet. 2020;395:497-506. doi: 10.1016/S0140$6736(20) 30183-5$

4. Lee HY. Is the distance "2.5" or "3" Ran on the weekend. Sisa Journal. 2020. http://www.sisajournal.com/news/ articleView.html?idxno=204417(Korean).

5. $\quad \mathrm{Im} \mathrm{JH}$, Jung SW. The reason why the number of confirmed persons does not drop sharply even in 
the '2.5 stage' of the distance that the headquarters director Jung Eun-kyung says. Insight. 2020. https://m. insight.co.kr/ news/303121(Korean).

6. JY Song, JG Yun, JY Noh, HJ Cheong, WJ Kim. Covid-19 in South Korea - Challenges of Subclinical Manifestations. N Eng/J Med. 2020; 382(19):1858-1859. doi: 10.1056/

\section{NEJMc2001801}

Gwon TH. Seoul City "Found the first case of infection in 8,544 general citizens at preemptive inspection". SBS News; 2020. https://news.sbs.co.kr/news/endPage. do?news_id=N1005984516(Korean) 